\title{
Incidence and prognostic factors of cranial and spinal choriocarcinomas
}

\author{
Gıyas AYBERK¹, Mahmut Nedim AYTEKIN² \\ 'Department of Neurosurgery, Ankara Yıldırım Beyazıt University, Ankara, Turkey \\ ${ }^{2}$ Department of Orthopedics and Traumatology, Ankara Yıldırım Beyazıt University, Ankara, Turkey \\ Correspondence \\ GIyas AYBERK \\ Ankara Yıldırım Beyazıt Üniversitesi Tıp Fakültesi Nöroşirürji Bölümü, Üniversiteler Mah, Bilkent cad, No:1, 06800, Çankaya, Ankara, Türkiye \\ e-mail: giyas67@hotmail.com
}

\begin{abstract}
Choriocarcinoma is a malignant germ cell tumor. Cranial and spinal lesions of choriocarcinoma are very rare. No large population-based studies have reported on cranial and spinal choriocarcinomas. This study aimed to describe the demographic factors of choriocarcinomas using the Surveillance, Epidemiology, and End Results (SEER) database.

This study was identified from the SEER database between 1973 and 2019. Histology, age, sex, and tumor location were evaluated. The results were compared with those of the previous studies.

The study comprised 16 patients. The mean age at diagnosis was 14.5 years. Thirteen (81.25\%) patients were younger than 18 years. The most common locations of the tumor were the pineal region of the brain $(43.75 \%, 7 / 16)$ and the neuroendocrine system $(50 \%, 8 / 16)$. No spinal choriocarcinomas were detected.
\end{abstract}

In conclusion, cranial choriocarcinoma is a rare malignancy that most commonly occurs in the pineal area. Its incidence is high for individuals younger than 18 years.

Key words: Choriocarcinoma, cranial, SEER, spine

\section{INTRODUCTION}

Choriocarcinomas are malignant nongerminomatous germ cell tumors that are very rare and constitute $3 \%-5 \%$ of all germ cell tumors $(2,13)$. They are highly resistant to standard treatment and have a poor prognosis with a median survival of less than 2 years (6). Choriocarcinomas grow very fast and can metastasize to the lung, liver, and less frequently to the brain and spinal canal $(1,3,12)$. They can cause intracranial bleeding when metastasized to the brain. ${ }^{12}$ Choriocarcinomas can also be seen as primary tumors in the central nervous system (CNS) $(7,10,11)$. Primary intracranial choriocarcinomas are usually localized in the pineal and suprasellar regions $(5-7,13)$. Tumors outside the pineal and suprasellar regions have a better prognosis (2). Patients undergoing total resection have a better prognosis than those with partial or subtotal resection. Metastasis is a predictive factor for poor prognosis (2).
The Surveillance, Epidemiology, and End Results (SEER) program of the National Cancer Institute is a population-based recording system that contains tumor data from approximately $34.6 \%$ of the population of the United States. This study aimed to describe the demographic factors of choriocarcinomas using the SEER database.

\section{METHODS}

\section{Patient selection}

Choriocarcinomas were identified using the SEER database [ICCC site rec extended ICD-O-3/WHO $2008=X(a .5)]$. Intracranial and intraspinal choriocarcinomas were screened in the database. The brain, NOS (C71.9.0), cerebrum (C71.0), overlapping lesions of the brain (C71.8), pineal gland (C75.3), parietal lobe (C71.3), ventricle (C71.5), and pituitary gland (C75.1) were taken to represent skull base lesions. Gender, 
race, age, year of diagnosis, tumor size, tumor extension, survival time after diagnosis, cause of death, extent of surgical resection, and patient information related to surgery and radiation sequence were included.

\section{Ethics approval}

Ethical approval and informed consent were not required for this study. Data could be accessed free of charge from the SEER database.

\section{RESULTS}

\section{Demographic analysis}

A total of 16 patients ( 14 male and 2 female) were included in this study. The mean age of the patients was 14.5 years ( 15.36 and 8.5 years for male and female patients, respectively). Moreover, $13(81.25 \%)$ patients were younger than 18 years and $3(18.75 \%)$ were older than 18 years. Further, both female patients were younger than 18 years. All patients were single.

\section{Diagnosis and treatment}

The most common locations of the tumor were the pineal region of the brain $(43.75 \%, 7 / 16)$ and the neuroendocrine system $(50 \%, 8 / 16)$ (Table 1$)$.
No spinal choriocarcinomas were detected. The second most common lesion locations were the cerebrum $(12.5 \%, 2 / 16)$ and the overlapping lesion $(12.5 \%, 2 / 16)$ (Table 1). Moreover, 62.5\% (5/8) patients with neuroendocrine system lesions were lost to the follow-up, and $50 \%$ (4/8 patients) patients with non-neuroendocrine brain involvement were lost during the follow-up (Table 2). The survival rate was 60 months for patients with tumors located in the neuroendocrine system and 27 months for those with non-neuroendocrine tumors. Ten patients underwent surgical treatment and six did not (Tables $3-4)$. Moreover, 60\% (6/10) patients who underwent surgery and $50 \%$ (3/6) patients who did not undergo surgery were lost to follow-up (Table 3 ). The survival rate was 42.3 months in patients who underwent surgical treatment and 42.4 months in those who did not undergo surgical treatment (Table 4).

\section{DISCUSSION}

Choriocarcinomas are the most malignant group of gestational trophoblastic tumors $(7,11)$. They constitute $3 \%-5 \%$ of all germ cell tumors $(2,13)$. Their median age is 30 years. They are frequently found in the gonads but may be extragonadal, too. Extragonadal choriocarcinomas occur at an early age and are

Table 1: Analysis of neuroendocrine system choriocarcinoma in the SEER database

\begin{tabular}{|c|c|c|c|c|c|c|}
\hline Patient & Sex & Age at diagnosis & $\begin{array}{l}\text { Primary site - } \\
\text { labeled }\end{array}$ & $\begin{array}{l}\text { Reason for no cancer- } \\
\text { directed surgery }\end{array}$ & $\begin{array}{l}\text { Survival } \\
\text { months }\end{array}$ & $\begin{array}{l}\text { Vital status } \\
\text { recode }\end{array}$ \\
\hline 1 & Male & 21 & Pineal gland & $\begin{array}{l}\text { Unknown; death } \\
\text { certificate; or autopsy only } \\
(2003+)\end{array}$ & 369 & Alive \\
\hline 2 & Female & 17 & Pineal gland & $\begin{array}{l}\text { Recommended but not } \\
\text { performed, unknown } \\
\text { reason }\end{array}$ & 65 & Dead \\
\hline 3 & Male & 12 & Pituitary gland & Surgery performed & 186 & Dead \\
\hline 4 & Male & 16 & Pineal gland & Not recommended & 89 & Alive \\
\hline 5 & Male & 16 & Pineal gland & Surgery performed & 15 & Dead \\
\hline 6 & Male & 18 & Pineal gland & Not recommended & 0 & Dead \\
\hline 7 & Male & 14 & Pineal gland & Surgery performed & 10 & Alive \\
\hline 8 & Male & 17 & Pineal gland & Surgery performed & 55 & Dead \\
\hline
\end{tabular}


Table 2: Analysis of non-neuroendocrine system choriocarcinoma in the SEER database

\begin{tabular}{|c|c|c|c|c|c|c|}
\hline Patient & Sex & $\begin{array}{l}\text { Age at } \\
\text { diagnosis }\end{array}$ & Primary site - labeled & $\begin{array}{l}\text { Reason for no cancer-directed } \\
\text { surgery }\end{array}$ & $\begin{array}{l}\text { Survival } \\
\text { months }\end{array}$ & $\begin{array}{l}\text { Vital status } \\
\text { recode }\end{array}$ \\
\hline 1 & Male & 18 & Ventricle, NOS & Surgery performed & 0 & Dead \\
\hline 2 & Female & 0 & Parietal lobe & Surgery performed & 99 & Alive \\
\hline 3 & Male & 14 & Cerebrum & Surgery performed & 16 & Dead \\
\hline 4 & Male & 20 & Cerebrum & Surgery performed & 0 & Dead \\
\hline 5 & Male & 9 & Cerebrum & Surgery performed & 28 & Alive \\
\hline 6 & Male & 27 & Overlapping lesion of the brain & Not recommended & 0 & Dead \\
\hline 7 & Male & 0 & Brain, NOS & Not recommended & 59 & Alive \\
\hline 8 & Male & 13 & Overlapping lesion of the brain & Surgery performed & 14 & Alive \\
\hline
\end{tabular}

Table 3: Analysis of patients with cranial choriocarcinoma who underwent surgery in the SEER database.

\begin{tabular}{|c|c|c|c|c|c|}
\hline Patient & Sex & Age at diagnosis & Primary site - labeled & Vital status recode & Survival months \\
\hline 1 & Male & 18 & Ventricle, NOS & Dead & 0 \\
\hline 2 & Male & 12 & Pituitary gland & Dead & 186 \\
\hline 3 & Female & 0 & Parietal lobe & Alive & 99 \\
\hline 4 & Male & 14 & Cerebrum & Dead & 16 \\
\hline 5 & Male & 20 & Cerebrum & Dead & 0 \\
\hline 6 & Male & 16 & Pineal gland & Dead & 15 \\
\hline 7 & Male & 9 & Cerebrum & Alive & 28 \\
\hline 8 & Male & 14 & Pineal gland & Alive & 10 \\
\hline 9 & Male & 17 & Pineal gland & Dead & 55 \\
\hline 10 & Male & 13 & Overlapping lesion of the brain & Alive & 14 \\
\hline
\end{tabular}

Table 4: Analysis of patients with cranial choriocarcinoma who did not undergo surgery in the SEER database

\begin{tabular}{|c|c|c|c|c|c|}
\hline Patient & Sex & Age at diagnosis & Primary site - labeled & Vital status recode & Survival months \\
\hline 1 & Male & 21 & Pineal gland & Alive & 369 \\
\hline 2 & Female & 17 & Pineal gland & Dead & 65 \\
\hline 3 & Male & 16 & Pineal gland & Alive & 89 \\
\hline 4 & Male & 27 & Overlapping lesion of the brain & Dead & 0 \\
\hline 5 & Male & 0 & Brain, NOS & Alive & 59 \\
\hline 6 & Male & 18 & Pineal gland & Dead & 0 \\
\hline
\end{tabular}

often seen in midline locations such as mediastinum, retroperitoneum, and pineal gland $(8,9)$. They are highly resistant to standard treatments. They are frequently seen in the pineal and suprasellar regions of the CNS $(5-7,10)$. They are more prone to malignancy when seen in this region (2).
Intracranial single or multiple aneurysms are seen in choriocarcinomas $(4,12)$. Intracranial choriocarcinomas may cause hemorrhages in the subarachnoid and intracerebral regions (12). Choriocarcinomas are rarely seen in many regions of the brain and also the spinal region $(1,3)$. In this study, the 
mean age was 14.5 years ( 15.36 years for males and 8.5 years for females). Intracranial choriocarcinomas were found to be predominant in patients younger than 18 years. Male dominance was also determined (female/male: $14.3 \%$ ). In this study, the most frequently affected area of the brain was the pineal region (43.75\%), including other regions of the brain. No spinal choriocarcinomas were detected.

As choriocarcinomas are very rare in the CNS, no clinical trials have reported the treatment of these tumors, except the standard treatment strategies. For this reason, the neurosurgeons have adopted surgical strategies for the treatment $(4,5,10,11)$. As shown in this study, the tendency of the surgeons was mostly toward surgical treatment, but no sig-

\section{REFERENCES}

1. Ishiguro T, Serikawa T, Yahata T, Enomoto T: Gestational choriocarcinoma: Rare spinal metastasis during a viable pregnancy. J Obstet Gynaecol Res 43:421-424, 2017

2. Jiang T, Raynald, Yang H, Zhang W, Li C: Predictive factors of overall survival in primary intracranial pure choriocarcinoma. J Clin Neurosci 61:93-101, 2019

3. Ko JK, Cha SH, Lee $\mathrm{JH}$, Choi $\mathrm{CH}$ : Intramedullary spinal cord metastasis of choriocarcinoma. J Korean Neurosurg Soc 51:141-143, 2012

4. Krege S, Beyer J, Souchon R, Albers P, Albrecht W, Algaba F, et al: European consensus conference on diagnosis and treatment of germ cell cancer: a report of the second meeting of the European Germ Cell Cancer Consensus group (EGCCCG): part I. Eur Urol 53:478-496, 2008

5. Li X, Murayama K, Watanabe A, Abe M, Toyama H: Primary Intracranial Choriocarcinoma Located in the Suprasellar Region. Open Neuroimag J 10:80-84, 2016

6. Matsutani M, Sano K, Takakura K, Fujimaki T, Nakamura O, Funata N, et al: Primary intracranial germ cell tumors: a clinical analysis of 153 histologically verified cases. J Neurosurg 86:446455, 1997 nificant difference between surgical and nonsurgical procedures was found.

This study had some limitations: 1) none of the cases were pathologically confirmed; 2 ) the limits of the surgical treatment were not clear, and whether the patients received a nonsurgical treatment could not be verified; 3 ) the sample size was small; and 4) the survival analyses were not sufficient.

\section{CONCLUSIONS}

Cranial choriocarcinomas are very rare. They usually occur in patients younger than 18 years. The pineal region is the most common localization in CNS. Although very few studies have reported spinal choriocarcinoma, it was not found in this study.

7. Mufti ST, Jamal A: Primary intracranial germ cell tumors. Asian J Neurosurg 7:197-202, 2012

8. Qiu J, Jia S, Li G: Incidence and prognosis factors of extragonadal choriocarcinoma in males: a population-based study. Cancer Manag Res 10:4565-4573, 2018

9. Schmoll HJ: Extragonadal germ cell tumors. Ann Oncol 13 Suppl 4:265-272, 2002

10. Sharma $M$, Velho $V$, Binayake $R$, Tiwari C: Primary intracranial choriocarcinoma presenting as a ring-enhancing lesion: A case report and review of literature. Asian J Neurosurg 12:85-88, 2017

11. Siddiahgari SR, Agarwal S, Reddy VK, Raju S, Jayashankar E, Palwai VR: Primary intracranial choriocarcinoma in a very youngest child. Pediatr Blood Cancer 64, 2017

12. Wang D, Shu H, Zhang Q, Zhang H, Qing C, Wang H: Brain metastasis of choriocarcinoma presenting as multiple intracranial hematomas: A case report. Medicine (Baltimore) 97:e12275, 2018

13. Wildi-Runge S, Crevier L, Carret AS, Robitaille Y, Deal C: Pituitary choriocarcinoma in an adolescent male: tumor-derived CG and GH delay diagnosis. Growth Horm IGF Res 21:181-184, 2011 